\title{
INTRALOBULAR AND INTRACELLULAR LOCALIZATION OF ALCOHOL DEHYDROGENASE (ADH) ISOZYMES IN MOUSE LIVER: BASIC ADH (CLASS I) AND ACIDIC ADH (CLASS III)
}

Takeshi Haseba ${ }^{1}$, Shigeru Sato ${ }^{2}$, Masamichi Ishizaki ${ }^{3}$, Isao Yamamoto $^{1}$, Mitsuyasu Kurosu ${ }^{1}$ and TOKINORI WATANABE ${ }^{1}$

${ }^{1}$ Department of Legal Medicine, ${ }^{2}$ Central Institute for Electron Microscopic Researches, and ${ }^{3}$ Department of Pathology, Nippon Medical School, Sendagi, Bunkyoku, Tokyo 113, Japan

\begin{abstract}
Localization of alcohol dehydrogenase isozymes [basic alcohol dehydrogenase (ADH): Class I and acidic ADH: Class III] was studied at both lobular and cellular levels in mouse liver by using immunohistological methods. The immunofluorescent microscopy showed that the basic ADH is distributed more predominantly in the perivenous zone than in the periportal zone, although the enzyme was detected in every parenchymal cell within the whole hepatic lobule. By immunoelectron microscopy, the enzyme was shown to distribute within the cytoplasmic matrix of hepatocytes, except for glycogen areas. On the other hand, acidic ADH was found to localize mainly on the periphery of the parenchymal cell, showing no distinct localization within the liver lobule by the immunofluorescent microscopy. The immunoelectron microscopic study confirmed that the acidic ADH localizes in the sinusoidal endothelial cells of the liver and revealed that the enzyme is also distributed in phagocytotic vesicles within hepatocytes. Thus, the basic and acidic ADH isozymes localize differently from each other in mouse liver tissue including parenchymal and nonparenchymal cells. These findings suggest that ADH isozymes may play different roles from each other in alcohol metabolism in the liver, not only at the enzymic property level but also at the cellular level.
\end{abstract}

It is generally accepted that alcohol dehydrogenase (ADH) (EC 1.1.1.1) is a key enzyme in alcohol metabolism in mammalian liver. During metabolism of alcohol, the enzyme produces the highly toxic acetaldehyde and also large amounts of $\mathrm{NADH}$, shifting the cellular redox potential to the reduced state and thus leading to heavy disturbances of the cell metabolism. The enzyme is therefore thought to play a significant role in the pathology of alcohol intoxication $(27,28,34,39)$.

Mammalian liver ADH isozymes are grouped into 3 classes (Classes I, II and III) $(3,16,22,38)$. Class I enzymes are very sensitive to pyrazole, and have a low $\mathrm{Km}$ for ethanol and a basic $\mathrm{pI}$ [human ADH isozymes with $\alpha, \beta, \gamma$ subunits (38) and mouse basic $\mathrm{ADH}$ (16) or $\mathrm{ADH} \mathrm{A}_{2}$ (3)]. Class III enzymes are insensitive to pyrazole, and have a very high $\mathrm{Km}$ for ethanol and an acidic $\mathrm{pI}$ [human $x$-ADH (33) and mouse acidic ADH (14-16) or $\mathrm{ADH} \mathrm{B}_{2}(3)$ ]. Class II enzymes have intermediate properties between Class I and Class III and their contents in the liver are low [human $\pi$-ADH (4), mouse $\mathrm{ADH}-\beta$ (16)].

Localization of ADH within the liver lobule has been studied from a pathological point of view by various methods. The results, however, have inconsistently demonstrated its centrilobular $(7,25,30)$, or periportal $(11,12,29)$ localization. In these studies, the Class I ADH isozymes have been solely focused on because the isozymes have been believed to play a main role in ethanol metabolism, whereas the other two classes of ADHs have been 
recently found and few studies on their roles in alcohol metabolism in vivo have been reported.

A recent study using $\mathrm{ADH}^{-}$deer mouse, genetically deficient in ADH (Class I), has revealed the existence of a significant metabolic pathway of alcohol, which is independent on Class I ADH (8).

We have recently reported that mouse liver acidic ADH (Class III) is increased in its activity during acute alcohol intoxication (17) and that human liver $x$-ADH (Class III) increases its activity corresponding to the increase of total alcohol intake (24). These data suggest a relationship between Class III ADH and alcohol metabolism or alcoholic liver disease.

In this study we investigated the localization of acidic ADH (Class III) and basic ADH (Class I) in mouse liver by immunofluorescence and immunoelectron microscopy using the isozyme-specific antibodies, and discussed the relationship between isozyme localization in the liver and alcohol metabolism or alcoholic liver disease.

\section{MATERIALS AND METHODS}

\section{Purification of Acidic and Basic ADH from Mouse Liver}

Livers (237 g) of ddY male mice (10 weeks old) were homogenized in $3 \mathrm{vol}(\mathrm{w} / \mathrm{v})$ of an extraction buffer [0.5 mM NAD/0.65 mM dithiothreitol (DTT)/ $5 \mathrm{mM}$ Tris-HCl, pH 8.5] with an Ultra Turax homogenizer. The homogenate was centrifuged at $105,000 \mathrm{~g}$ for $1 \mathrm{~h}$ to obtain liver extract. The extract was dialyzed against $0.5 \mathrm{mM} \mathrm{NAD} / 0.65 \mathrm{mM}$ DTT/ $5 \mathrm{mM}$ phosphate buffer (PB), pH 6.8, and then applied to a CM-cellulose column equilibrated with the same buffer. Acidic ADH fraction passing through the CM column was chromatographed on a DEAE-cellulose column by a linear PB gradient (5-100 mM) supplemented with $0.5 \mathrm{mM}$ NAD and $0.65 \mathrm{mM}$ DTT. The eluted enzyme fraction was dialyzed against $10 \mathrm{mM} \mathrm{PB}, \mathrm{pH} 7.4$ and applied to a Blue Sepharose column equilibrated with the same buffer. The enzyme was eluted from the column by a linear gradient of NAD $(0-1.5 \mathrm{mM})$ in the PB containing $16 \mathrm{mM}$ hexenol. After the affinity chromatography, the enzyme fraction was concentrated and then gel-filtered using a Toyo pearl column eqilibrated with $10 \mathrm{mM} \mathrm{PB}, \mathrm{pH} 7.4$ (14).

Basic ADH was eluted from the CM-cellulose column by a linear PB gradient $(5-100 \mathrm{mM})$ supplemented with $0.5 \mathrm{mM}$ NAD and $0.65 \mathrm{mM}$ DTT.
The eluted enzyme fraction was dialyzed against $10 \mathrm{mM} \mathrm{PB}, \mathrm{pH} 7.4$ and applied to a Blue Sepharose column. The enzyme was eluted from the column by a linear gradient of NAD $(0-1.5 \mathrm{mM})$ in the buffer containing $14 \mathrm{mM}$ ethanol and then gelfiltered by a Toyo pearl chromatography.

$\mathrm{ADH}$ activity was assayed at $37^{\circ} \mathrm{C}$ in $0.1 \mathrm{M}$ glycine buffer ( $\mathrm{pH}$ 10.7) containing $1.7 \mathrm{mM}$ NAD and substrate ( $7 \mathrm{mM}$ hexenol for acidic ADH, $14 \mathrm{mM}$ ethanol for basic ADH) at $340 \mathrm{~nm}$ using a Simadzu UV-300 Autoscan spectrophotometer.

Protein concentration was determined with BCA Protein Assay Reagent (Pierce, Rockford, IL).

The purity of the final enzyme preparations was checked by electrophoresis on a gradient SDSpolyacrylamide gel (10-20\%) according to the method of Laemmli (26) and molecular weight of ADH was estimated using High Molecular Weight Standard Mixture (Sigma, St. Louis, MO).

\section{Preparation of Antibody against Acidic or Basic $A D H$}

Antibody was raised in rabbits by subcutaneous injection of purified $\mathrm{ADH}$ isozyme ( $1 \mathrm{mg}$ each protein/animal) emulsified in Freund's complete adjuvant (Difco, Detroit, MI) $(1: 1, \mathrm{v} / \mathrm{v})$. After 1 week, the same dose of the emulsion was injected into the animal. Additional immunization by two intravenous injections with enzyme protein alone $(0.2 \mathrm{mg}$ each/animal) followed at weekly intervals. The rabbit was bled from the heart on the 5 th week, and the antiserum was collected. Preimmune serum samples collected prior to the first injection served as controls.

\section{Evaluation of Antibody Specificity}

The antiserum was tested by double immunodiffusion in 1.2\% agarose (See Kem LE, Marine Collids, Rockland, ME) according to Ouchterlony (32).

Western blot analysis was performed according to Towbin et al. (37) with nitrocellulose filter [Schlei \& Schuell, cellulosenitrat (E), BA $85,0.45 \mu \mathrm{m}$, Ref. No. 401196] after electrophoresis on a gradient SDS-polyacrylamide gel. Immuno-reaction on the filter was detected by the biotin-avidin technique (20).

Immunocross-reactivities between the mouse $\mathrm{ADH}$ isozymes (acidic, basic and $\mathrm{ADH}-\beta$ ) were studied by alkaline disc electrophoresis of antibodytreated liver extract $(14,16)$. 


\section{Fluorescence Microscopy}

According to Ishizaki et al. (21), blocks of fresh mouse liver (ddY, male, 8 weeks old) were placed on a filter paper and immediately frozen in liquid $n$ hexane which was chilled with dry-ice-acetone. Tissue sections (2-3 $\mu \mathrm{m}$ in thickness) were prepared in a cryostat at $-20^{\circ} \mathrm{C}$, fixed in acetone $\left(-20^{\circ} \mathrm{C}\right)$ for $10 \mathrm{~min}$ and washed with phosphate-buffered saline (PBS) for $10 \mathrm{~min}$ at $25^{\circ} \mathrm{C}$.

For indirect immunofluorescence staining, the sections were incubated with properly diluted antiserum against mouse $\mathrm{ADH}$ isozyme at $25^{\circ} \mathrm{C}$ for 30 min. After washes in PBS for 5 min (3 times), the sections were stained with FITC-labeled antirabbit IgG, goat antibody (Miles-Yeda, Elkhart, IN) at $25^{\circ} \mathrm{C}$ for $30 \mathrm{~min}$, and then washed again with PBS for 5 min ( 3 times). All reagents were obtained from commercial sources and checked by immunoelectrophoresis.

The stained sections were mounted with 50\% glycerine in $0.5 \mathrm{M}$ carbonate buffer, $\mathrm{pH} 9.5$, and examined on an Olympus BHF fluorescent microscope.

As controls, tissue sections were incubated with normal rabbit serum.

\section{Immunoelectron Microscopy}

Immunoelectron microscopy using peroxidaselabeled antibody was performed as described by Yamada and Nakane (41). Fresh mouse liver was immediately fixed in periodate-lysine-paraformaldehyde fixative (PLP) $\left(0.01 \mathrm{M} \mathrm{NaIO}_{4}, 0.075 \mathrm{M}\right.$ lysine, $0.0375 \mathrm{M}$ sodium phosphate buffer, $2 \%$ paraformaldehyde) for $6 \mathrm{~h}$. The tissue was then washed overnight in $0.05 \mathrm{M}$ PBS (pH 7.4) with $10 \%$ sucrose, PBS with $15 \%$ sucrose for $12 \mathrm{~h}$, and PBS with $15 \%$ sucrose and $10 \%$ glycerol for $2 \mathrm{~h}$. The resulting tissues were embedded in OCT compounds (Lab-Tek Products, Napaville, IL) with $10 \%$ glycerol, quick-frozen in liquid nitrogen and stored at $-70^{\circ} \mathrm{C}$. The $4 \mu \mathrm{m}$ frozen sections cut in a cryostat were mounted on glass slides coated with egg albumin and washed 3 times in PBS with 10\% sucrose. For indirect immunohistochemical staining, the tissue sections were incubated at $4^{\circ} \mathrm{C}$ overnight with antiserum against mouse $\mathrm{ADH}$ isozyme.

The sections were washed with PBS containing $10 \%$ sucrose ( 8 times) at $4^{\circ} \mathrm{C}$ for $12 \mathrm{~h}$, then incubated at $4^{\circ} \mathrm{C}$ overnight with horseradish peroxidase
(HRPO)-labeled anti-rabbit IgG, goat antibody (Miles, Elkhart, IN) diluted 1:16 with the buffer. The tissue sections were washed 8 times at $4^{\circ} \mathrm{C}$ for $12 \mathrm{~h}$ with the buffer. After postfixation in $2 \%$ glutalaldehyde for $20 \mathrm{~min}$, the sections were reacted with $0.02 \%$ diaminobenzidine (DAB) $/ 0.05 \%$ hydrogen peroxide for $10 \mathrm{~min}$, fixed in $2 \%$ osmium tetroxide for $30 \mathrm{~min}$, dehydrated in a graded series of ethanol to $100 \%$. The sections were embedded by inverting a capsule filled with SPUR (Polysciences, Warrington, PA) onto the sections and polymerized in an oven. The blocks were examined by light microscopy to select positively stained areas. Ultrathin sections of these areas were cut on an LKB ultramicrotome and examined without additional staining or with uranyl acetate staining under a Hitachi 12A electron microscope. As controls, tissue sections were incubated with normal rabbit serum diluted 1:16 with PBS containing $10 \%$ sucrose.

\section{RESULTS}

Purification of Acidic and Basic ADH Isozymes Results of purification of both ADH isozymes were summarized in Table 1, $a$ and $b$. Each purified preparation of $\mathrm{ADH}$ isozyme formed a single protein band around $38 \mathrm{~K}$ (acidic $\mathrm{ADH}$ ) or $37 \mathrm{~K}$ (basic $\mathrm{ADH}$ ) by electrophoresis on a gradient SDS-polyacrylamide gel (Fig. 1). The molecular weight value of acidic ADH was almost the same as that reported previously (14) and the value of basic ADH was close to that of Class I ADHs (5).

\section{Evaluation of Antibody Specificity against Mouse ADH Isozyme}

Double immunodiffusion test of each antiserum against acidic or basic ADH showed a single precipitation line with mouse liver extract (data not shown). Western blot analysis using each antiserum also formed a single band around $38 \mathrm{~K}$ (acidic $\mathrm{ADH}$ ) or $37 \mathrm{~K}$ (basic ADH) on nitrocellulose filter where liver extract proteins and purified acidic $\mathrm{ADH}$ or purified basic ADH were transferred after SDS-gradient gel electrophoresis (Fig. 2, A and B).

To check immunocross-reactivity between ADH isozymes of mouse liver, the antibody-treated liver extract was applied to alkaline electrophoresis. As shown in Fig. 3B, the antiserum against acidic $A D H$ reacted only with that enzyme, not with the other isozymes (basic ADH and ADH- $\beta$ ). The anti- 
Table 1a Purification of Acidic ADH from Mouse Liver

\begin{tabular}{lccccc}
\hline \multicolumn{1}{c}{ Purification step } & $\begin{array}{c}\text { Total protein } \\
(\mathrm{mg})\end{array}$ & $\begin{array}{c}\text { Total activity } \\
\text { (units) }\end{array}$ & $\begin{array}{c}\text { Specific activity } \\
\text { (units/mg) }\end{array}$ & $\begin{array}{c}\text { Purification } \\
\text { (fold) }\end{array}$ & $\begin{array}{c}\text { Yield } \\
\text { (\%) }\end{array}$ \\
\hline Liver extract & $13,827.5$ & $1,054.3$ & 0.076 & 1 & 100 \\
CM-chromatography & $11,300.3$ & 839.5 & 0.074 & 0.97 & 79.6 \\
$\begin{array}{l}\text { DEAE-chromatography } \\
\begin{array}{l}\text { Blue Sepharose- } \\
\text { chromatography }\end{array}\end{array}$ & 432.2 & 349.3 & 0.81 & 10.7 & 33.1 \\
$\begin{array}{l}\text { Toyo pearl gel } \\
\quad \text { filtration }\end{array}$ & 26.4 & 285.4 & 10.81 & 142.2 & 27.1 \\
\hline
\end{tabular}

Table 1b Purification of Basic ADH from Mouse Liver

\begin{tabular}{lccccc}
\hline \multicolumn{1}{c}{ Purification step } & $\begin{array}{c}\text { Total protein } \\
\text { (mg) }\end{array}$ & $\begin{array}{c}\text { Total activity } \\
\text { (units) }\end{array}$ & $\begin{array}{c}\text { Specific activity } \\
\text { (units/mg) }\end{array}$ & $\begin{array}{c}\text { Purification } \\
\text { (fold) }\end{array}$ & $\begin{array}{c}\text { Yield } \\
(\%)\end{array}$ \\
\hline Liver extract & $13,827.5$ & 871.2 & 0.063 & 1 & 100 \\
$\begin{array}{l}\text { CM-chromatography } \\
\begin{array}{l}\text { Blue Sepharose- } \\
\text { chromatography }\end{array}\end{array}$ & 793.5 & 335.4 & 0.42 & 6.7 & 38.5 \\
$\begin{array}{l}\text { Toyo pearl gel } \\
\text { filtration }\end{array}$ & 23.6 & 132.2 & 5.60 & 88.9 & 15.2 \\
\hline
\end{tabular}

Activities of acidic $\mathrm{ADH}$ and basic $\mathrm{ADH}$ were measured for hexenol $(7 \mathrm{mM})$ and ethanol $(14 \mathrm{mM})$ as substrates, respectively. For details, see Matelials and Methods.

serum against basic ADH also reacted only with that enzyme, not with the others (Fig. 3C).

These data demonstrate that each antiserum is monospecific for each ADH isozyme.

\section{Immunofluorescent Microscopic Study on Localization of ADH Isozyme}

Basic ADH Strong and almost even staining of the parenchymal cells around the pericentral area was found when sections of normal mouse liver were incubated with the antiserum against basic ADH (Fig. 4A). The fluorescence around the periportal area tended to be darker, indicating a lower amount of basic ADH in this area than in the pericentral area. No fluorescence was seen in nuclei of the parenchymal cells.

Acidic ADH With the antiserum against acidic ADH, strong stainings were seen on the periphery of the parenchymal cells, and cells themselves were also faintly stained, showing no distinct localization within the liver lobule (Fig. 4B).

Control Almost even darkness was seen in all tissue area, when the section was incubated with normal rabbit serum prepared from preimmune rabbit (data not shown).

\section{Immunoelectron Microscopic Study on Localization of ADH Isozyme}

Basic $A D H \quad$ By the treatment of the sections with the antiserum against basic $\mathrm{ADH}$, granular depositions of the peroxidase reaction product were almost evenly distributed in the cytoplasm of the hepatocyte, except for the glycogen areas (Fig. 5).

Acidic ADH With the antiserum against acidic $\mathrm{ADH}$, strong reaction products were seen on sinusoidal walls, which were constituted mainly of sinusoidal endothelial cells (Fig. 6).

Fig. 7 shows that the peroxidase reaction products derived from the antiserum were mainly found in sinusoidal endothelial cells. The products were additionally seen in spaces between endothelial cells and hepatocytes (Disse space), and also in phagocytotic vesicles of the hepatocyte.

\section{DISCUSSION}

\section{Localization of Basic ADH}

The previous studies of the intralobular localization of ADH in the liver have yielded conflicting results when the enzyme activity was used as an indicator, partly because the substrate conditions 


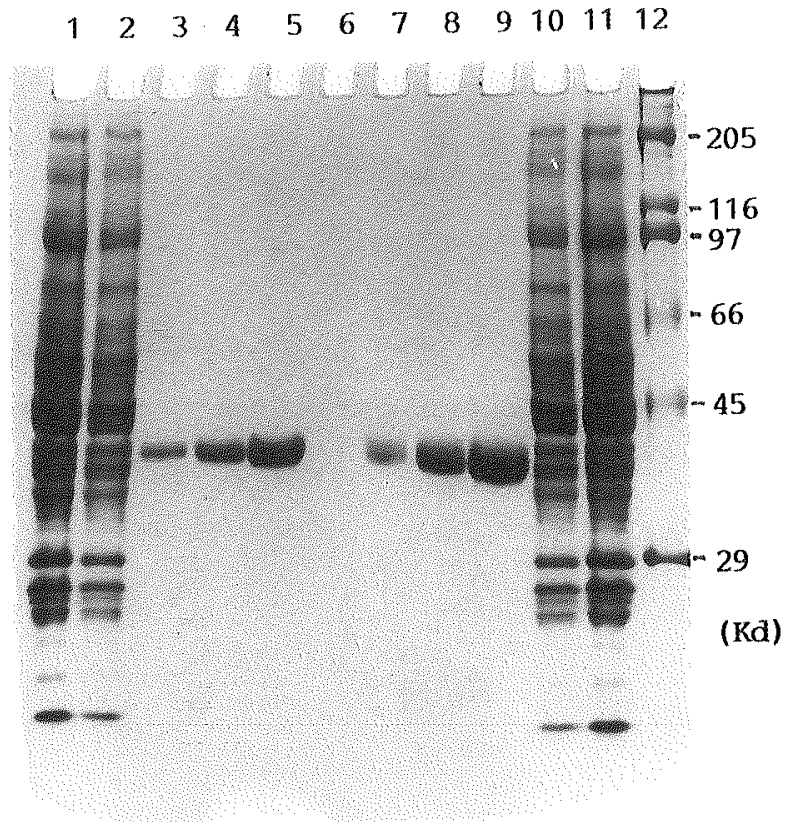

Fig. 1 SDS electrophoresis of purified acidic $\mathrm{ADH}$ and basic ADH on 10-20\% gradient polyacrylamide gel. Protein samples were treated with $1 \%$ 2-mercaptoethanol/ $1 \% \mathrm{SDS}$ at $100^{\circ} \mathrm{C}$ for $2 \mathrm{~min}$ and subjected to electrophoresis with a slab gel $(8.4 \times 9.0 \times 0.1 \mathrm{~cm})$ and $0.1 \%$ SDS/25 mM Tris-glycine buffer, $\mathrm{pH}$ 8.4. Protein bands were stained with $0.25 \%$ Coomassie brilliant blue $\mathrm{R}$ in $10 \%$ acetic acid $/ 50 \%$ methanol. Lanes $1,2,10,11$, liver extract proteins $(86,43,43,86 \mu \mathrm{g})$; lanes $3,4,5$, acidic $\operatorname{ADH}(1.9,4.8,9.6 \mu \mathrm{g})$; lanes $7,8,9$, basic ADH $(2.6,6.5$, $12.9 \mu \mathrm{g}$ ); lane 12 , molecular size markers

were different $(11,12,25,29,30)$. High concentrations of ethanol $(0.5-1.2 \mathrm{M})(25,40)$ or $0.4 \mathrm{M}$ propanol (11) used as substrate to detect ADH in the several papers, are not specific for detection of each $\mathrm{ADH}$ isozyme. In general the techniques using enzyme activity as an indicator [histochemistry $(11,25,40)$, microdissection (30), separation of isolated hepatocytes $(12,29)$ ] have the common difficulty in discriminating various isozymes (23). If $\mathrm{ADH}$ isozymes localize differently in liver tissue, the results of the localization studies could be changed depending on substrate conditions, because the ADH isozymes have the different substrate specificities from each other (16). Therefore, it is necessary to apply immunohistochemical methods using isozyme-specific antibody to identify each isozyme in the localization study. Immunohistochemical techniques have demonstrated the perivenous localization of ADH both in human

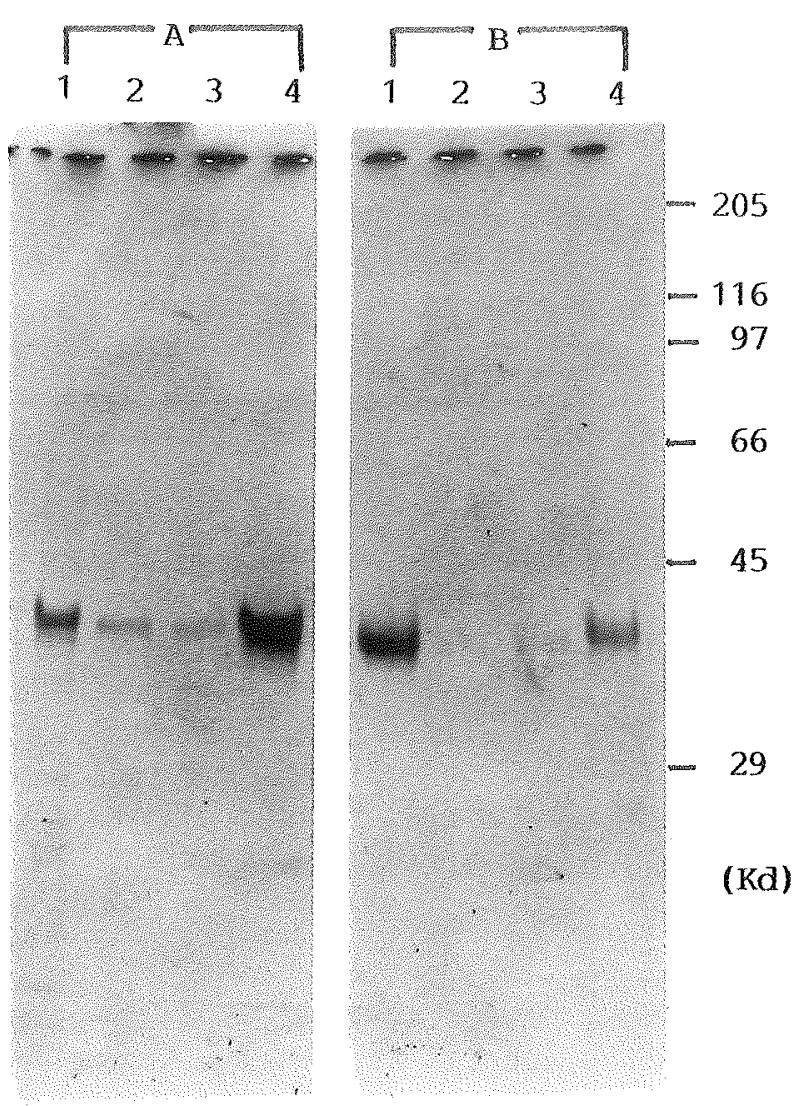

Fig. 2 Western blot analyses of acidic ADH (A) and basic ADH (B). Enzyme protein was electrophoresed on a gradient SDS-gel as in Fig. 1, and transferred to a nitrocellulose filter by electroblotting at $0.8 \mathrm{~mA} / \mathrm{cm}^{2}$ for $1 \mathrm{~h}$ in $25 \mathrm{mM}$ Tris-glycine buffer (pH 8.4) containing $20 \%$ methanol. The filter blot was blocked with $3 \%$ bovine serum albumin (BSA) $/ 10 \%$ horse serum (HS)/TBS (0.2 M NaCl/0.5 M Tris-HCl buffer, $\mathrm{pH} 7.4$ ) for $1 \mathrm{~h}$ at $25^{\circ} \mathrm{C}$, washed with $0.1 \% \mathrm{HS} / \mathrm{TBS}$ for $10 \mathrm{~min}, 3$ times and then incubated with isozyme-specific antiserum in $3 \%$ BSA $/ 10 \% \mathrm{HS} / \mathrm{TBS}$ at $4^{\circ} \mathrm{C}$ overnight. After rewashing and reblocking, the blot was incubated with biotin-conjugated anti-rabbit IgG in 3\% BSA/5\% HS/TBS for $1.5 \mathrm{~h}$ at $25^{\circ} \mathrm{C}$, washed with $\mathrm{TBS}(10 \mathrm{~min}, 3$ times) and then incubated with avidin-labeled horseradish peroxidase in $3 \% \mathrm{BSA} / 5 \% \mathrm{HS} / \mathrm{TBS}$ for $45 \mathrm{~min}$ at $25^{\circ} \mathrm{C}$. Colouring reaction was done with $0.1 \% 3,3^{\prime}$-diaminobenzidine tetrahydrochloride $/ 15 \mathrm{mM}$ imidazole $/ 0.01 \% \mathrm{H}_{2} \mathrm{O}_{2} / \mathrm{TBS}$ after washing with $0.05 \%$ Tween $20 /$ TBS for 6 min, 2 times and with TBS for $6 \mathrm{~min}, 3$ times. A: antiserum against acidic $\mathrm{ADH}$, lanes 1, 2, 3, liver extract proteins $(4.4,0.8,0.4 \mu \mathrm{g})$; lane 4 , purified acidic ADH $(0.2 \mu \mathrm{g}) ; \mathrm{B}$ : antiserum against basic $\mathrm{ADH}$, lane 1 , purified basic $\mathrm{ADH}(0.2 \mu \mathrm{g})$; lanes $2,3,4$, liver extract proteins $(0.4$, $0.8,4.4 \mu \mathrm{g})$ 
(7) and rat (25) livers.

Our immunohistological study using the isozyme-specific antibody also confirmed the perivenous distribution of basic ADH (Class I) in mouse liver lobule, although the perivenous localization was not so predominant (Fig. 4A), when compared with the results in rat (25) and human (7) livers.

From these immunohistological results in mammalian livers, it may be possible to conclude that Class I ADH proteins localize predominantly around the perivenous area (Zone III) in the liver lobule.

However, it is necessary to take into consideration that the localization of Class I ADH may be changed within the liver lobule, depending on the condition of liver. Several reports have demonstrated the periportal localization of ADH activity in isolated hepatocytes $(12,29)$, even under the exclusive substrate conditions for Class I ADH. Several enzymes involved in glycolysis or glycogenesis are known to shift their localizations within the liver lobule as a result of starvation (35) or hepatectomy (6).

The intracellular localization of ADH in hepatocyte has been investigated by Watabiki (40) using ultracytochemical staining. ADH within mouse hepatocyte localizes unevenly in the cytoplasmic matrix, especially in close proximity to the rough endoplasmic reticula or mitochondria, and within the mitochondria (40).

In Watabiki's study, however, ADH was detected by enzyme activity with $1.2 \mathrm{M}$ ethanol as substrate, with which acidic ADH shows predominant activity rather than basic $\mathrm{ADH}$. In addition, the ultracytochemical technique may be seriously affected by endogenous NADH or diffusion of the enzymereaction products.

Our data by immunoelectron microscopy showed that basic ADH localizes evenly within the cytoplasmic matrix of the hepatocyte, except for glycogen areas, and not in nuclei and mitochondria (Fig. 5). This result is supported by the biochemical data that ADH activity was negligible in organelle fractions when ethanol was used as substrate $(9,31)$.

\section{Localization of Acidic ADH}

Our study using the immunofluorescent microscopy showed that acidic ADH localized mainly on the periphery of the parenchymal cells and slightly within the cells themselves, although the intra-

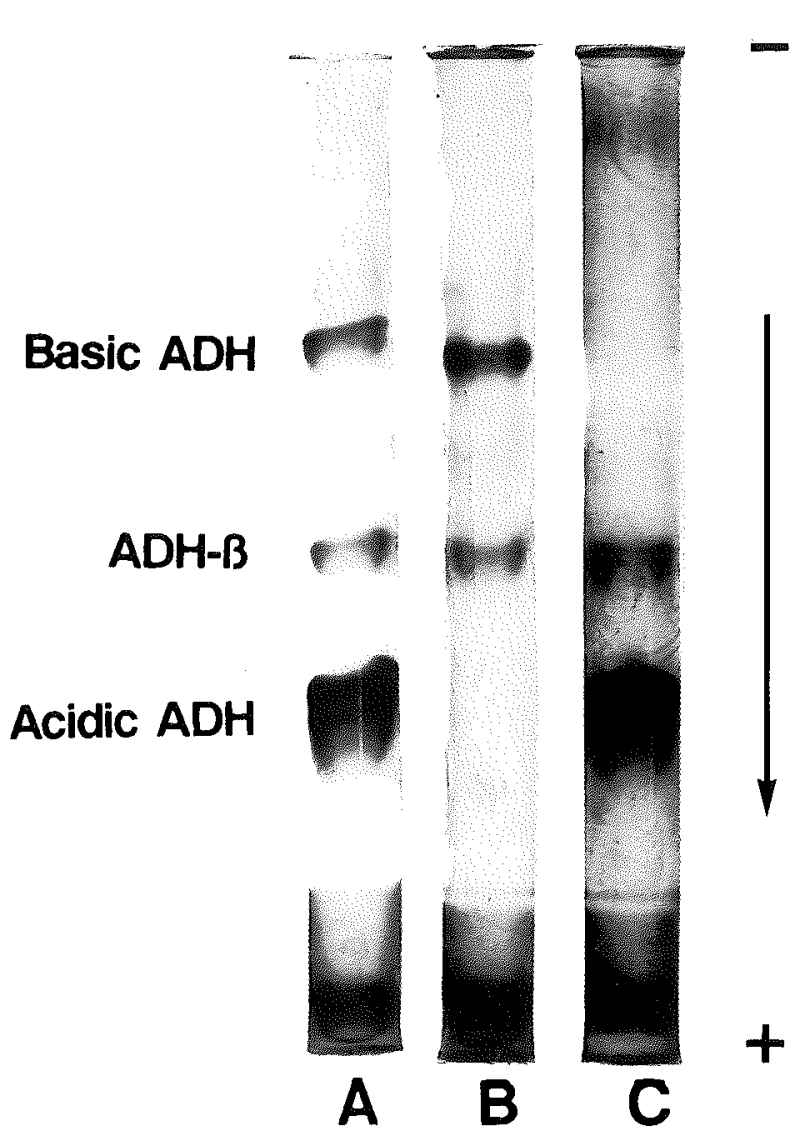

Fig. 3 Disc electrophoresis of alcohol dehydrogenase isozymes in the mouse liver extract after treatment with isozyme-specific antibody. The liver extract was treated with antiserum or control serum at $4^{\circ} \mathrm{C}$ for $2 \mathrm{~h}$ and then centrifuged at $8,000 \mathrm{~g}$ for $10 \mathrm{~min}$. The supernatant was subjected to electrophoresis on $7.5 \%$ acrylamide gel (0.1 M L-arginine buffer, pH 9.7) using $0.5 \mathrm{mM}$ NAD/ $40 \mathrm{mM} \beta$-alanine/3.5 mM L-arginine buffer, $\mathrm{pH} 9.0$. The enzyme was stained with $2.2 \mathrm{mM} \mathrm{NAD} / 7 \mathrm{mM}$ hexenol/ $0.8 \mathrm{mM}$ neotetrazolium/1.4 mM PMS/0.1 M glycine buffer, $\mathrm{pH}$ 10.7. A, control serum; $\mathrm{B}$, anti-acidic $\mathrm{ADH}$ antibody; $\mathrm{C}$, anti-basic $\mathrm{ADH}$ antibody

lobular localization was almost even both in the peripheries and in the cells (Fig. 4B). The immunoelectron microscopy revealed precisely that the enzyme was localized in sinusoidal endothelial cells (Figs. 6 and 7). In addition, the enzyme was distributed in Disse spaces and in hepatocyte, where the enzyme was in phagocytotic vesicles (Fig. 7). These findings suggest that acidic ADH is synthesized in the sinusoidal endothelial cell and then transported to the hepatocyte.

Different from Class I and Class II ADH iso- 

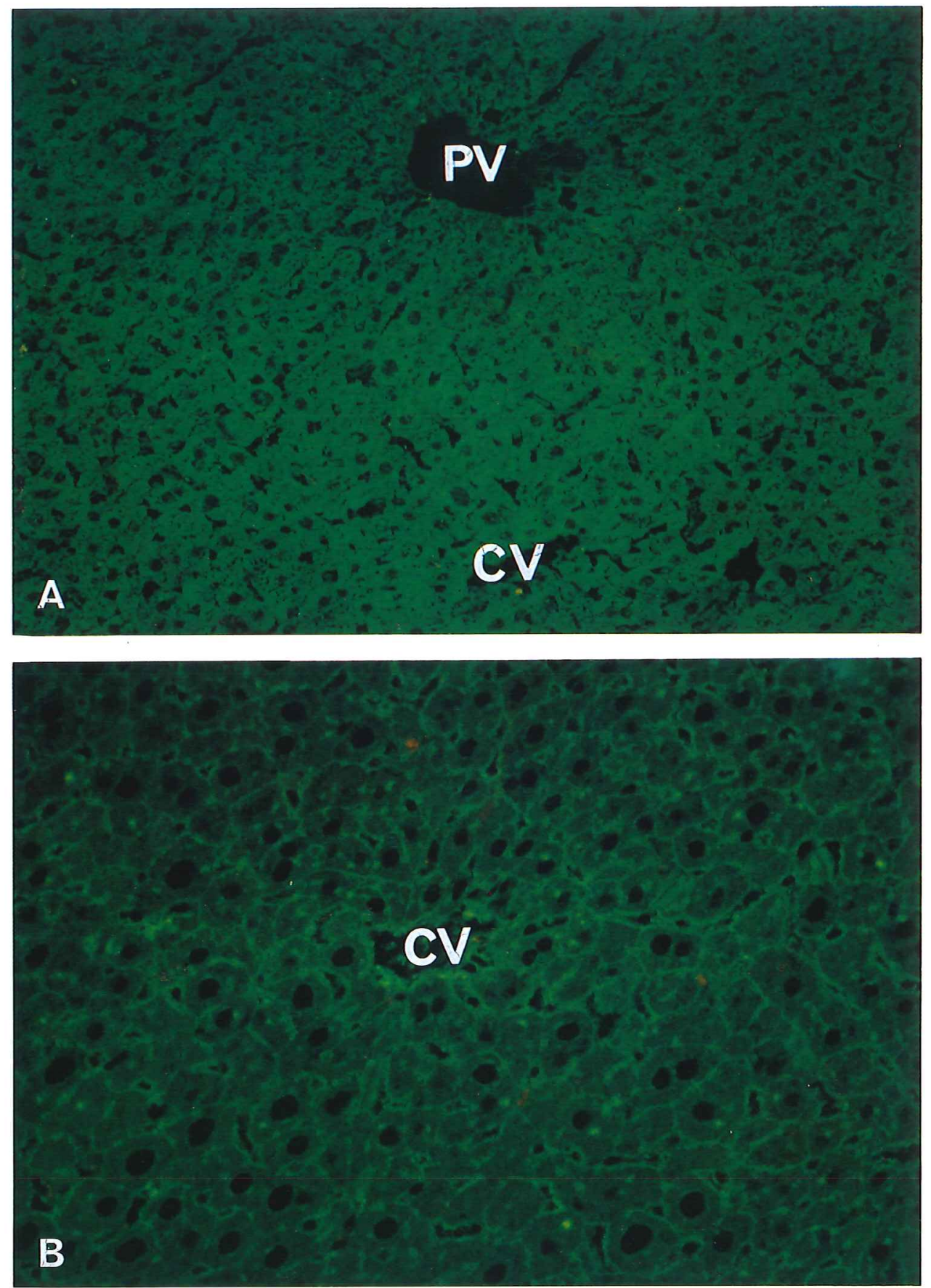

Fig. 4 Indirect immunofluorescent staining of $\mathrm{ADH}$ isozyme in sections of mouse liver. Section was stained with FITC-conjugated goat anti-rabbit IgG after incubation with antiserum against $\mathrm{ADH}$ isozyme. $\mathrm{A}$, anti-basic $\mathrm{ADH}$ antibody; $\mathrm{B}$, anti-acidic $\mathrm{ADH}$ antibody; PV, portal vein; CV, central vein. A $: \times 300, \mathrm{~B}: \times 600$ 


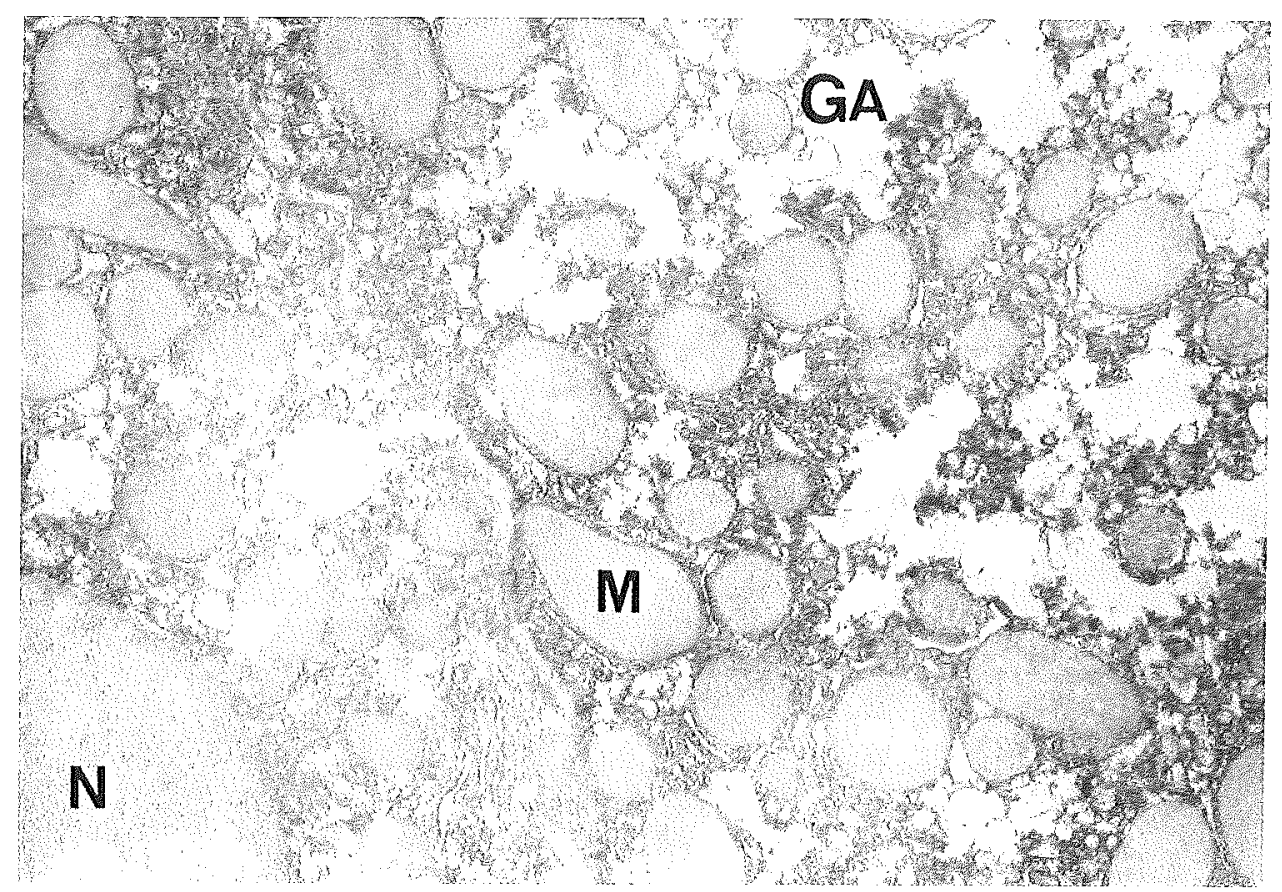

Fig. 5 Electron micrograph of immunoperoxidase reaction in mouse liver section incubated with anti-basic ADH antibody. Electron-dense reaction products are present within cytoplasmic matrix of hepatocyte except for glycogen areas (GA). M, mitochondrion; N, nucleus. $\times 13,200$

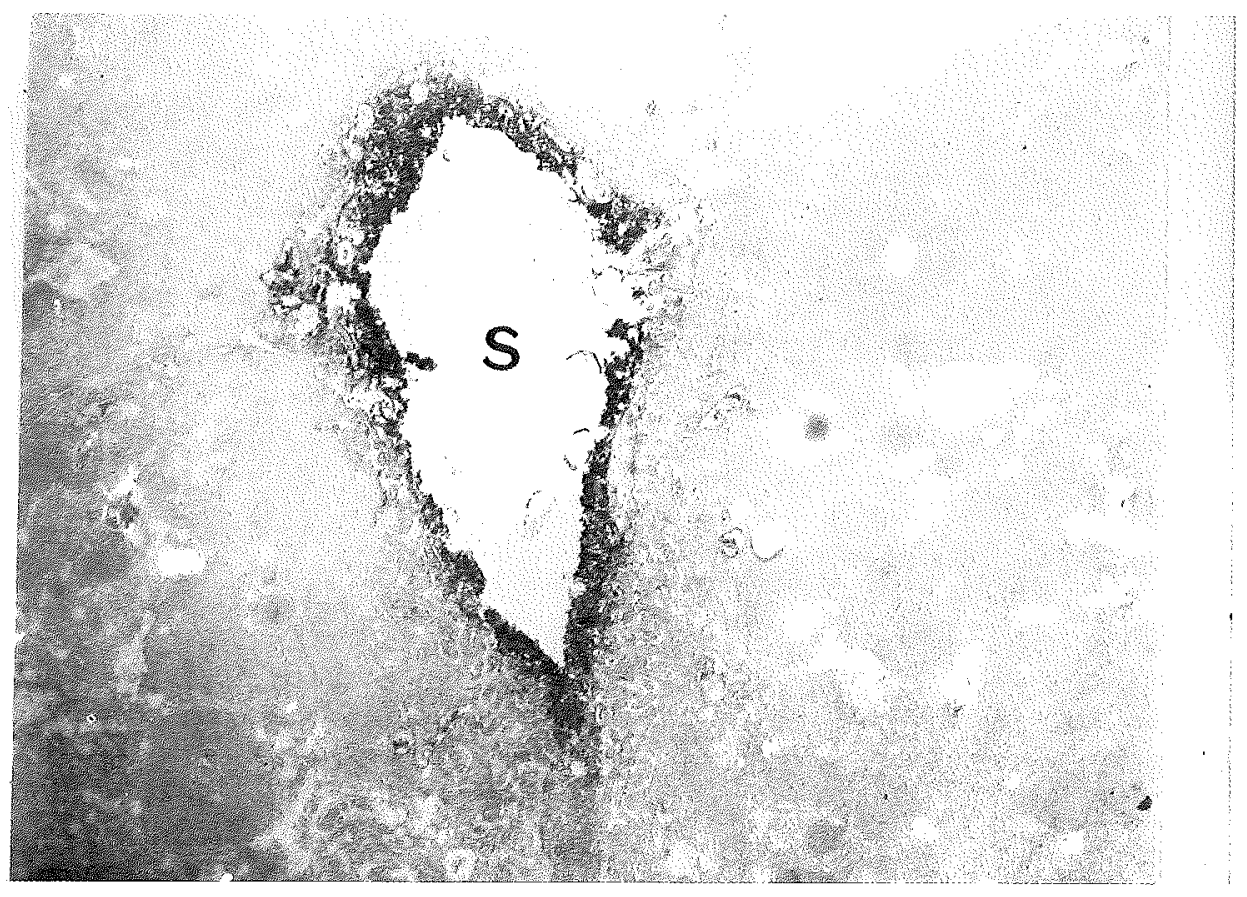

Fig. 6 Electron micrograph of immunoperoxidase reaction in mouse liver section incubated with anti-acidic ADH antibody. Electron-dense reaction products are present mainly on sinusoidal wall where enothelial cells locate. S, sinusoid. $\times 11,000$ 


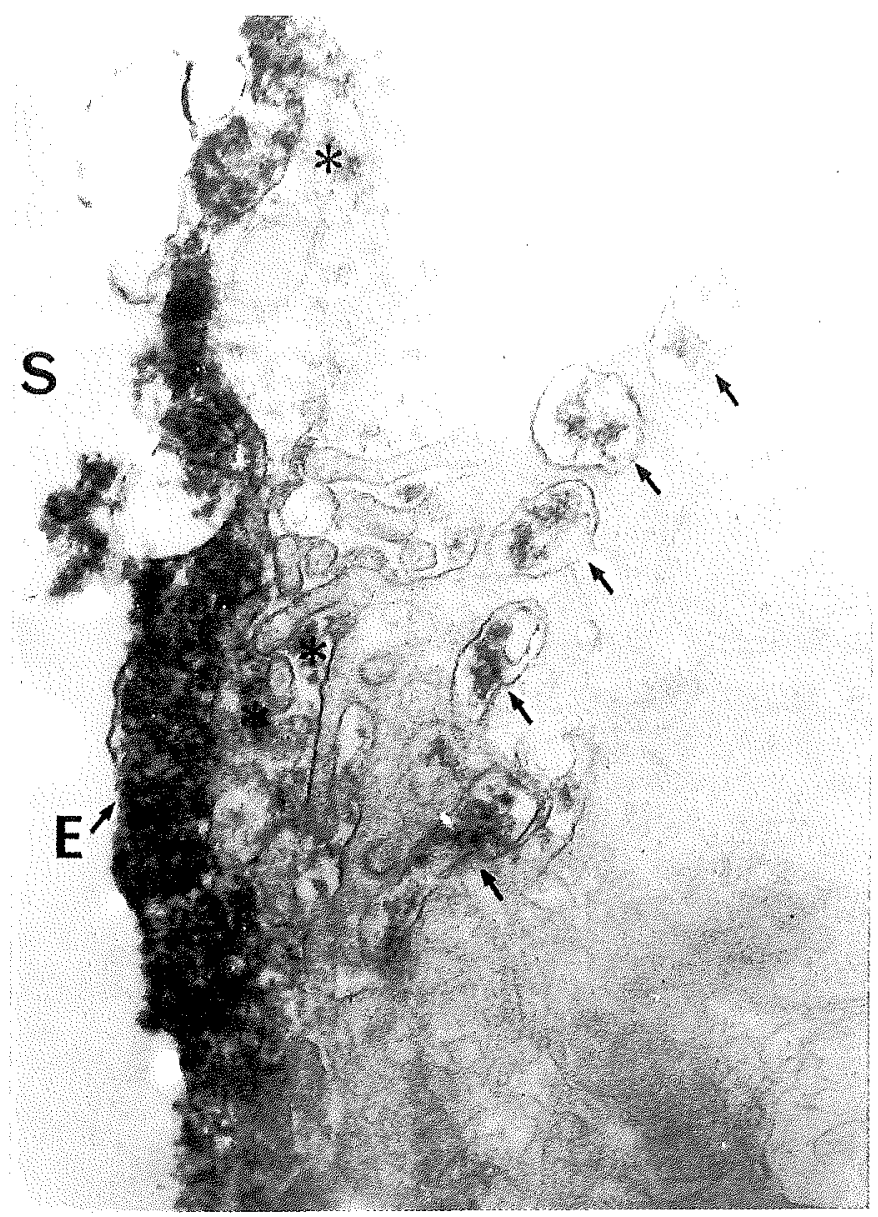

Fig. 7 Electron micrograph of immunoperoxidase reaction in mouse liver section incubated with anti-acidic ADH antibody. Electron-dense reaction products are present in endothelial cells $(\mathrm{E})$, Disse space $(*)$ and phagocytotic vesicles (arrow) in hepatocyte. S, sinusoid. $\times 34,000$

zymes, Class III ADHs including acidic ADH are known to distribute in all mammalian tissues examined by electrophoretic analysis $(1,18,19)$. Therefore, our data on the localization of acidic ADH in the sinusoidal endothelial cell suggests the universal localization of Class III ADHs in the endothelial cell of the capillary.

\section{Alcohol Metabolism and Alcoholic Liver Disease}

We previously discussed the possible roles of acidic $\mathrm{ADH}$ and basic $\mathrm{ADH}$ in alcohol metabolism during acute alcohol intoxication, based on their different $\mathrm{Km}$ for ethanol $(14,18)$, and the difference in the change of the two enzyme acitivities in the liver of ethanol-intoxicated mice (17).

Basic ADH shows maximum activity around $15 \mathrm{mM}$ ethanol which corresponds to the blood alcohol concentration on intaking $180 \mathrm{ml}$ (Ichi-go) of sake (Japanese wine) (14). On the other hand, acidic ADH increases its activity up to $3 \mathrm{M}$ of ethanol, corresponding to the concentration of ethanol in sake (14).

It is known that ethanol in concentrations considerably higher than in the peripheral blood reaches the sinusoid of liver through the portal vein after drinking $(10,13)$.

In this study the two ADH isozymes were found 
to localize in different cell types (parenchymal and sinusoidal endothelial cell) in liver (Figs. 5, 6 and 7). By combining the enzymological and localization data, it is suggested that acidic ADH in sinusoidal endothelial cells may function as the first step in ethanol metabolism in liver to protect the parenchymal cells from the toxicity of high concentrations of ethanol. Basic ADH may mainly participate in the second step in ethanol metabolism in parenchymal cells, after the ethanol concentration was reduced by acidic ADH in sinusoidal endothelial cells.

Thus, the two ADH isozymes may have different roles in liver alcohol metabolism not only at the enzymatic property level, but also at the cellular level.

Furthermore, our co-worker demonstrated previously that corresponding to the increase in the total alcohol intake, the activity of human liver $x$ ADH (Class III) increases in alcoholic liver diseases, while the activity of Class I ADH decreases (24). Such reverse changes in the two $\mathrm{ADH}$ isozyme activities in the liver diseases may be due to the difference in localization of the isozymes in liver tissue. Alcoholic liver diseases are known to involve capillarization of the sinusoid accompanied by fibrosis and breakdown of the parenchymal cells (36). The site-specific injury in liver lobule is also known to be chracteristic of the alcoholic liver diseases and has been discussed in relation to the localization of $\mathrm{ADH}$ in the tissue $(7,25,30)$. Taken together, Class III ADH in endothelial cells may play a more important role in alcohol metabolism in alcoholic liver diseases and may relate to the sitespecific injury of the liver diseases such as pericellular fibrosis, which is frequently seen in alcoholic liver diseases (2).

This study was supported in part by a grant-in-aid from the Ministry of Education, Science and Culture, Japan (No. 60480198).

Received 6 February 1991; and accepted 18 April 1991

\section{REFERENCES}

1. Adinolfi A., Adinolfi M. and Hopkinson D. A. (1984) Immunological and biochemical characterization of the human alcohol dehydrogenase $x$-ADH isozyme. Ann. Hum. Genet. 48, 1-10

2. Aimara M. (1984) A histopathological study of alcoholic liver fibrosis, especially on characteristic changes of perisinusoidal reticulin fibers. Kanzo 29, 491-500 (in Japanese)
3. Algar E. M., Seeley T.-L. and Holmes R. S. (1983) Purification and molecular properties of mouse alcohol dehydrogenase isozymes. Eur. J. Biochem. 137, 139-147

4. Bosron W. F., Li T.-K., Dafeldecker W. P. and Vallee B. L. (1979) Human liver $\pi$-alcohol dehydrogenase: Kinetic and molecular properties. Biochemistry 18, 1101-1105

5. BrändÉn C.-I., Jörnvall H., Eklund H. and Furugren B. (1975) Alcohol dehydrogenases. In The Enzymes (ed. Boyer P. D.) Academic Press, New York; pp. 103-190

6. Brinkmann A., Katz N., Sasse D. and Jungermann K. (1978) Increase of the gluconeogenic and decrease of the glycolytic capacity of rat liver with a change of the metabolic zonation after partial hepatectomy. Z. Physiol. Chem. 359, 1561-1571

7. Buehler R., Hess M. and Von Wartburg J.-P. (1982) Immunohistochemical localization of human liver alcohol dehydrogenase in liver tissue, cultured fibroblasts, and HeLa cells. Amer. J. Pathol. 108, 89-99

8. Burnett K. G. and Felder M. R. (1980) Ethanol metabolism in peromyscus genetically dificient in alcohol dehydrogenase. Biochem. Pharmacol. 29, 125-130

9. Buttner H. (1965) Aldehyd- und AlkoholdehydogenaseAktivität in Leber und Niere der Ratte. Biochem. Z. 341, 300-314

10. Falconer B. and Gladnikoff H. (1934) Über den Alkoholgehalt des Blutes verschiedener gafäße bein Kaninchen nach Alkoholzufuhr. Scand. Arch. Physiol. 63, 245-251

11. Greenberger N. J., Cohen R. B. and Isselbacher K. J. (1965) The effect of chronic ethanol administration on liver alcohol dehydrogenase activity in the rat. Lab. Invest. 14, 264-271

12. Gumucio J. J., Demason L. J., Miller D. L., Krezoski S. O. and KeENER M. (1978) Induction of cytochrome P-450 in a selective subpopulation of hepatocytes. Amer. $J$. Physiol. 234, C102-C109

13. Halsted C. H., Robles E. A. and Mezey E. (1973) Distribution of ethanol in the human gastrointestinal tract. Amer: J. Clin. Nutr. 26, 831-834

14. Haseba T. (1985) Acidic pI-alcohol dehydrogenase of mouse liver: Purification and characterization. Jap. J. Alc. \& Drug Dependence 20, 333-349 (in Japanese)

15. Haseba T., Hirakawa K., Nihira M., Hayashida M., Kurosu M., Tomita Y., Ide T. and Watanabe T. (1979) Partial purification and characterization of mouse liver alcohol dehydrogenase. Jap. J. Stud. Alc. 14, 324 (in Japanese)

16. Haseba T., Hirakawa K., Tomita Y. and Watanabe T. (1984) Characterization of high $\mathrm{Km}$ alcohol dehydrogenase from mouse liver. In Electrophoresis (ed. HiraI H.) Walter de Gruyter \& Co., Berlin, pp. 393-400

17. Haseba T., Kurosu M., Tomita Y., Hayashida M., Hirakawa K., Nihira M., Watanabe T. and Kadowaki M. (1986) A study of the change of the mouse liver ADH activity after alcohol administration. Jap. J. Alc. \& Drug Dependence 21, S34-35 (in Japanese)

18. Haseba T., Kurosu M., Tomita Y., Hirakawa K., KamiI H., Nihira M. and Watanabe T. (1987) Enzymatic properties of a pyrazole-insensitive alcohol dehydrogenase and its role on alcohol metabolism. Alcohol Metabolism and Liver 6, 18-28 (in Japanese)

19. Holmes R. S. (1978). Electrophoretic analyses of alcohol dehydrogenase, aldehyde dehydrogenase, aldehyde oxidase, sorbitol dehydrogenase and xanthine oxidase from mouse tissues. Comp. Biochem. Physiol. 61B, 339-346

20. Hurley W. L., Finkelstein E. and Holst B. D. (1985) 
Identification of surface proteins on bovine leukocytes by a biotin-avidin protein blotting technique. $J$. Immunol. Method 85, 195-202

21. Ishizaki M., Masuda Y., Fukuda Y., Sugisaki Y., YamaNAKA N. and MASUGI Y. (1986) Experimental mesangioproliferative glomerulonephritis in rats induced by intravenous administration of anti-thymocyte serum. Acta Pathol. Jap. 36, 1191-1203

22. Julià P., FARrÉs J. and PARÉs X. (1987) Characterization of three isoenzymes of rat alcohol dehydrogenase. Tissue distribution and physical and enzymatic properties. Eur. $J$. Biochem. 162, 179-189

23. Jungermann K. and Katz N. (1982) Functional hepatocellular heterogeneity. Hepatology 2, 385-395

24. KamII H. (1988) Pyrazole sensitive and pyrazole insensitive-alcohol dehydrogenase activities in biopsied livers of patients with alcoholic liver disease. J. Nippon Medical School 55, 4-14 (in Japanese)

25. Kato S., Ishit H., Airso S., Yamashita S., Sato J., Tsugi M., Ito D., TAKaGI T. and TsuchiYA M. (1986) Study on localization of alcohol dehydrogenase within liver lobule. Alcohol Metabolism and Liver 5, 7-11 (in Japanese)

26. LAEMMLI U. K. (1970) Cleavage of structural proteins during the assembly of the head of bacteriophage T4. Nature 227, 680-685

27. Li T.-K. (1977) Enzymology of human alcohol metabolism. Adv. Enzymol. 45, 427-483

28. Lieber C. S. and Davidson C. S. (1962) Some metabolic effects of ethyl alcohol. Amer. J. Med. 33, 319-327

29. Miyagawa H., Hasumura Y. and Takeuchi J. (1988) Study on localization of alcohol metabolizing enzymes within liver lobule using isolated hepatocytes from periportal and perivenous areas. Alcohol Metabolism and Liver 7, 124-132 (in Japanese)

30. Morrison G. R. and Brock F. E. (1967) Quantitative measurement of alcohol dehydrogenase in the lobule of nomal livers. J. Lab. Clin. Med. 70, 116-120
31. Nyberg A., Schuberth J, and ÄNGGärd L. (1953) On the intracellular distribution of catalase and alcohol dehydrogenase in horse, guinea pig and rat liver tissues. Acta Chem. Scand. 7, 1170-1172

32. Ouchterlony O. (1958) Duffusion in gel methods for immunological analysis. Allergy 5, 1-78

33. Parés X. and VAllee B. L. (1981) New human liver alcohol dehydrogenase forms with unique kinetic characteristics. Biochem. Biophys. Res. Commun. 98, 122-130

34. Pietruszko R. (1975) Mammalian liver alcohol dehydrogenases. Adv. Exp. Med. Biol. 56, 1-31

35. Sasse D., Katz N. and Jungermann K. (1975) Functional heterogeneity of rat liver parenchyma and of isolated hepatocytes. FEBS Lett. 57, 83-88

36. TAGUCHI K. (1987) Sinusoidal alteration in alcoholic liver injury with special reference to relationship between fibronectin and capillarization. Kanzo 28, 439-446 (in Japanese)

37. Towbin H., Staehelin T. and Gordon J. (1979) Electrophoretic transfer of proteins from polyacrylamide gels to nitrocellulose sheets: Procedure and some applications. Proc. Natl. Acad. Sci. USA. 76, 4350-4354

38. VALLEE B. L. and BAzzone T. J. (1983) Isozymes of human liver alcohol dehydrogenase. In Isozymes: Current Topics in Biological and Medical Research Vol. 8 (ed. RATTAZzI M. C., Scandalios J. G. and Whitt G. S.) Liss, New York, pp. 219-244

39. Von Wartburg J.-P. and Bühler R. (1984) Biology of disease. Alcoholism and aldehydism: New biomedical concepts. Lab. Invest. 50, 5-15

40. Watabiki T. (1979) Ultracytochemical study of alcohol dehydrogenase activity in nomal mouse hepatic cells. Acta Histochem. Cytochem. 12, 368-382

41. Yamada G. and NaKane P. K. (1977) Hepatitis B core and surface antigens in liver tissue. Light and electron microscopic localization by the peroxidase-labeled antibody method. Lab. Invest. 36, 649-659 